\title{
Background Music: Using Narrative Inquiry to Explore the Hidden Aspects of Musicians' Career Development
}

\author{
Nicole Canham \\ Monash University, Melbourne, Australia
}

The COVID-19 global pandemic has delivered a significant career shock at every level of the music sector, bringing with it renewed recognition of the vulnerability of many creative people. Multiple research approaches are needed to understand the consequences of the pandemic for musicians as workers and the ways in which musicians frame and describe their career choices. In this paper, I offer a way to amplify our listening to musicians' stories through combining narrative inquiry with a narrative therapy lens as a means of tuning into musicians' background music-the guiding beliefs that shape professional identity development and artistic practice. Simon's narrative portrait forms the centrepiece of this article. Through exploring how his approach to informal learning developed and sustained his professional identity, Simon's story demonstrates how a convergence framework of narrative inquiry and narrative therapy can be harnessed to understand identity continuity in musicians' careers and the ways in which musicians respond to career development challenges.

Keywords: narrative inquiry, career development, narrative therapy, musician formation

critical issue in music education and the music professions is that careers
in music can be unhealthy and unsustainable (Gross and Musgrave
2020). Musicians in many Western countries report levels of financial remuneration for their professional work and access to health care and adequate housing that are much lower than national averages (Skaggs, Frenette, Gaskill, and Miller 2017; Throsby and Peteskaya 2017). Musicians' narratives of forced career transitions highlight the sometimes-negative nature of these events in their lives, and the consequences of uncertain employment for musicians often result in feelings of lack of agency (Hennekam and Bennett 2016). Managing multiple, 
"incompatible" identities can also contribute to "stress and identity conflict" (Hennekam 2017, 971). It is perhaps not surprising, then, that musicians are at significantly higher risk of depression, anxiety, stress, and burnout than the general population (van den Eynde, Fisher, and Sonn 2015). The professional realities many musicians must negotiate go far beyond their talent or need for business skills: their work conditions are making them sick (Gross and Musgrave 2020).

The COVID-19 global pandemic has amplified this situation. The pandemic stimulated a sector-wide career shock (Akkermans, Richardson, and Kraimer 2020) with far-reaching repercussions including significant individual grief and loss (Blustein and Guarino 2020). This context has drawn attention to the significant psychological challenges posed by music working conditions, creating the need to reconsider popular ways of understanding musicians' work-related learning and the development of their professional identities. Much of the prior occupational research on musicians' career development is grounded on an opportunity structure approach, which has been an influential perspective in career development research (Furlong and Biggart 2006). An opportunity structure approach to career development research questions the structures that impact individuals or groups and acknowledges that most people will not fulfill their career aspirations. Training, employability, and entrepreneurship are at the heart of research activity in this area, yet, while useful, the opportunity structure approach fails to fully capture the extent of the subjective lived experience of musicians at all career stages, both prior to the pandemic and as the pandemic has unfolded (e.g., Cohen 2020, Morris 2020, Qian 2020, Savage 2020).

Scholars have written about the careers of professional musicians, including music portfolio careers and the range of roles musicians will likely undertake in their work (Bartleet et al. 2012, Bennett 2008, Davidson 2002); however, accounts of how musicians manage their work over time while maintaining a sense of identity continuity are limited. The pandemic has illustrated why we need more nuanced understandings of musicians beyond their opportunities, training, talent, or entrepreneurial skills. A person's guiding beliefs and values about work-which I describe as their career "background music"-provide the psychological context for their work-related choices, decision-making, and the meanings they derive from their work experiences (University of Strathclyde and Bimrose 2006). In this paper, I explore how the convergence of narrative inquiry and narrative therapy 
techniques drawn from career counselling may be harnessed to better understand a musician's identity continuity. Through Simon's narrative account, I highlight how and why overlaying narrative inquiry practices with career counselling techniques can deepen understanding of musicians' career background music, and how the convergence of narrative inquiry and narrative therapy can offer a muchneeded alternative for understanding career continuity and career development challenges and decisions in the lives of contemporary musicians.

\section{When Passion Is Not Enough}

It is increasingly evident that many musicians lack approaches that might enable them to effectively manage the complex practical and personal challenges that music careers often pose (Gross and Musgrave 2020). Individuals may not have the psychological constructs, such as psychological ownership (Olckers and Koekemoer 2017), that are required to navigate contemporary work. Psychological ownership includes sense of commitment, motivation, and satisfaction, as well as feelings of control. While links between career success and psychological ownership have been demonstrated (Olckers and Koekemoer 2017), many artists report that factors beyond their control negatively influence their careers (Throsby and Petetskaya 2017). To support career development in music, both researchers and educators-particularly educators at the tertiary level-have emphasised the potential of entrepreneurship education and the possibilities of self-employment as strategies for musicians (Bartleet et al. 2012, Beckman 2007, Bennett 2008, Bridgstock 2013). The fragility and vulnerability of musicians' work cannot be addressed through entrepreneurship or enterprise alone, however, and the COVID19 pandemic made the limitations of these approaches even more evident (Cohen 2020). Some musicians may not be well-suited to nor interested in becoming entrepreneurs, and even if they are, such training does not necessarily consider psychological ownership, professional identity, or identity continuity. Further, entry into the music professions is often difficult and protracted (Creech et al. 2008; Carroll 2010, 2015), making it perhaps even harder to gauge how professional identities in music are developed and sustained. A convergence framework of narrative inquiry and narrative therapy deployed in the study of musicians' career

Canham, Nicole. 2021. Background music: Using narrative inquiry to explore the hidden aspects of musicians' career development. Action, Criticism, and Theory for Music Education 20 (4): 146-70. https://doi.org/10.22176/act21.1.146 
development can enhance our understanding of identity continuity in music and what psychological ownership of a career in music looks like.

\section{Connecting Narrative Inquiry and Narrative Therapy}

The field of vocational psychology was founded by Frank Parsons (1909), who pioneered many of the approaches that underpin career counselling today. Parsons believed that client self-awareness and counsellor acknowledgement of client personal information, background, choices, and decision-making were central to the counselling process. Decades later, the introduction of constructivism into the career development field came about because "career practitioners [were] seeking approaches ... closer to the everyday situations of practice than those available to them through career research and theory" (Young and Collin, 2004, 374; Savickas 2011; Savickas 2013a). More recently, theories related to the psychology of work, including the meaning and purpose of work (Blustein 2006; Duffy, Blustein, Diemer, and Autin 2016; Yeoman 2014), have also impacted vocational psychology and career counselling, in part because the context for many workers has rapidly changed over the last three decades through the disruptive effect of digital technologies (Law, Meijers, and Wijers 2002). Career counselling theories have also been adapted to accommodate the increasingly prevalent factors of uncertainty and forced or unexpected change as well as factors that enable career actors to respond to "unplanned events" (Mitchell, Levin, and Krumboltz 1999, 117; Krumboltz 2009).

Michael White and David Epston pioneered narrative therapy in the 1970s and 1980s (White 2009). Narrative therapy shares similarities with narrative inquiry approaches identified by Barrett and Stauffer (2009), including an emphasis on relationship. In the therapy setting, counselling and the counselling relationship are viewed as a collaboration between an "unknowing" counsellor and the client. Narrative therapy is considered "a 'solution oriented' therapy, perhaps because the practices of narrative therapy provide people with new approaches to the predicaments of their lives" (White 2002, 35). How problems are understood in narrative therapy is an important part of finding new solutions, and "a respectful, non-blaming approach" (Morgan 2000,4) is paramount. In narrative therapy, the client is

Canham, Nicole. 2021. Background music: Using narrative inquiry to explore the hidden aspects of musicians' career development. Action, Criticism, and Theory for Music Education 20 (4): 146-70. https://doi.org/10.22176/act21.1.146 
viewed as the expert on the problem, and the counsellor collaborates with the client as they find solutions.

Counsellors using narrative therapy techniques maintain that clients already have many of the resources (beliefs and values, skills and abilities) needed to solve their problems/meet their needs, and they adopt a position of unconditional positive regard for the client (Morgan 2000). Foundational assumptions of narrative therapy point to the ways in which identity is formed and influenced through meaning, language, and context (Carr 1998). The counsellor attends to and explores the meanings people generate from their experiences, the language they choose to describe their experiences, and the ways in which this language reflects social structures and client positioning.

\section{The Importance of Stories}

Clients may select and narrate experiences that reinforce a dominant story, which in turn influences both present and future actions. The meaning the client ascribes to their stories forms the plot. Career counsellors using narrative principles, therefore, look to collaborate with clients to understand how clients link key life experiences and events over time through their stories. As an individual seeks out examples to support a particular plotline of experience, the story, whether helpful or unhelpful, becomes increasingly dominant (Morgan 2000). Stories can also be framed or re-framed from different perspectives, depending on the life stage of the person involved.

Narrative also plays an important part in the development of professional identity (Simosi, Rousseau, and Daskalaki 2015). Stets and Serpe (2013) define identity as "a shared set of meanings that define individuals in particular roles in society ... as members of specific groups in society ... and as persons having specific characteristics that make them unique from others" (31). Due to the wide range of roles people occupy in their lives, they maintain multiple identities, which may be obligatory or voluntary in nature (Stets and Serpe 2013). Narrative is at the heart of the expression of identities and of personality in and through identities and roles: McAdams and Olson (2010) observe that personality develops through "traits, adaptations, and narratives" (519). Three constructs are critical in this process: a person's behaviour (as "actor"), the way their actions are directed (as 
"agent"), and how these actions are explained to others (as "author")-their narratives (McAdams and Olson 2010; see also Savikas 2013b).

\section{Careers Research, Identity Continuity, and Music Careers}

Recent work in the career development field has made connections between employability (transferable skills) and individual psychological resources and identified them as career development meta-competencies (see for example Olckers and Koekemoer 2017). Potgieter (2012) demonstrated that a person's self-esteem, proactivity, and life circumstances significantly influence their employability. A heightened capacity to respond to work-related challenges, including finding, maintaining, and transitioning between jobs (employability), is connected to good mental health, which in turn is necessary for finding and sustaining solutions to ongoing uncertainty. Both employability and positive self-esteem are key for manoeuvring within and beyond existing opportunity structures. These findings highlight the influence of individual background factors, such as outlook on life and problem-solving, on work experiences and career outcomes.

In addition, developing and maintaining a sense of identity continuity is vitally important, especially as people age (Atchley 1989). Atchley's concept of identity continuity highlights the way "adults employ concepts of their past to conceive of their future and structure their choices" (183). Identity continuity is connected with a sense of "mastery and competence" (185) as well as a sense of integrity, selfesteem, and an ability to meet one's individual needs. Identity continuity is also influenced by "the picture of jobs and the workplace that others hold," and a person's background characteristics, their education, and personal circumstances, which influence their self-awareness, perceptions of their occupation, and their subsequent decision-making and planning (University of Strathclyde and Bimrose 2006, 8)-for this study, a person's background music.

Researchers therefore need to look more closely at the source/s of musicians' identity continuity and to understand its connections to their career-related beliefs, values, and behaviours. Although understanding how musical identities are developed is now well-established in the music field (e.g., MacDonald, Hargreaves, and Miell 2002), it is much less clear how musical identities support adult career development beliefs, values, and behaviours, which in turn may lead to satisfying 
and sustainable careers. Smilde (2009) highlights the ways in which informal learning, attitudes toward lifelong learning and many other aspects of a person's life story, in addition to their experiences of formal training, contribute to musicians' professional identities. However, it is unclear how people sustain a sense of personal and professional identity in an environment characterised by complexity, uncertainty, fear, and change (Canham 2021; see also Blustein and Guarino 2020).

Meijers and Kuijpers (2014) argue that, in a time of high work-related uncertainty, narrative approaches that inspire change are more useful than other careers content training (such as entrepreneurship) considered necessary. Extending music careers research more deeply into narrative territory through a convergence framework of narrative inquiry and narrative therapy aims at a conception of musicians' career development as a situated, problem-solving process related to their background music-the guiding beliefs that shape musicians' experiences of their work and professional identities. Barrett and Stauffer (2009) observe that "narrative work provides a means to re-conceptualise the ways in which we think about music engagement, music education, and inquiry in music education” (1), and Nichols and Brewer (2017) suggest that one of the benefits of narrative inquiry in music education research is that we might, through small stories, provide insight into "big ideas or critical issues" (9). Stauffer (2014) comments that "there is much to be learned from our colleagues in other disciplines who have been about the practice of narrative inquiry longer" (3). The purpose of combining narrative inquiry and narrative therapy approaches in this paper is to contribute to a bank of stories for those who need them most: musicians who are negotiating their career development on their own in a complex and uncertain profession.

\section{Using Stories to Address Shared Problems}

This paper centres around interviews with a mid-career musician named Simon. Simon was one of eight participants in a larger study conducted pre-Covid. ${ }^{1}$ I revisited his story, as I felt it might be helpful to others at this time. Although the purpose of our interviews was not therapeutic, the original research design followed many of the principles of narrative therapy. Counsellors using narrative principles aim to thicken client narratives (Morgan 2000). Thickening out a story may include asking questions that elicit memories of a specific situation or 
significant event, connecting events to time periods or life stages, and exploring what stories say about the client as a person (Carr 1998). I aimed to understand how mid-career musicians navigated their career development from the point of view of their identity continuity as expressed in and through their artistic work. Consistent with the principles of narrative therapy, the following research questions guided my emergent understanding of Simon's story, his career strengths, and the ways these strengths supported and sustained his identity continuity:

What is Simon's career background music, i.e., the guiding beliefs and values that underpin his narrative?

What decisions did Simon make based on his background music?

How does overlaying a narrative therapy approach to Simon's story alter or enhance its meaning?

Subjective experience significantly informs objective understanding of career development (Law et al. 2002). The combination of narrative inquiry and narrative therapy approaches enabled me to explore the ways independent artistic and career pathways are constructed and to uncover hidden and subjective aspects of participants' life, work, and learning.

In this paper, I focus on Simon's narrative because his story steps away from common narratives in musicians' career development research, which tend to focus on the limitations of tertiary training. Simon did not study music at the tertiary level, and so his interviews focused more on his own self-directed learning and career development solutions than other study participants, largely because Simon did not compare or associate his professional or career development experiences with a lengthy, influential period of formal music learning.

\section{Stories Within Stories}

I was curious to understand how other mid-career musicians had made sense of their formative learning experiences in music and the ways in which they had approached their own career development. My lengthy career as an independent professional musician informed both the scope and direction of the inquiry, which aimed to illuminate aspects of the beliefs and values that contribute to musicians' sense of independence. I was interested in better understanding these aspects of career development because my own experience of being a "portfolio musician"2 
was a source of significant career dissatisfaction. I had found the work pattern of maintaining several small, ineffectual identities that seemed to be useful in some realms but not others to be a waste of effort that did not support my larger career goals. I wanted to know how others developed and sustained a sense of identity continuity, which for me had been a very time consuming, sometimes frustrating, undertaking. The culmination of my research journey was returning to further study, after my $\mathrm{PhD}$, to train as a career counsellor. In addition to the lens of researcher as musician-colleague, therefore, I also brought the skills, knowledge, and experience of a career counsellor to this inquiry. I returned to Simon's interviews during the pandemic with a view to listening to his story not just as a researcher, but also as a career counsellor.

\section{Simon's Story}

Conversations about managing life and work originally prompted me to explore musicians' career development in my research. This paper includes excerpts from interviews with Simon, a musician based in the UK who has established a career as a composer for video games and film scores. In addition to his work as a composer, Simon runs a production company. Living one's career is an unmediated experience, and yet quite a lot of the occupational research explores the ways in which training mediates later work experiences, often through the false expectations the training sometimes generates or perpetuates. Simon's career pathway offered an alternative to this familiar narrative, as his formal music training stopped at the end of secondary school. In contrast to some studies of young musicians who may express that their training did not prepare them for the profession, Simon's career narrative was quite consistently framed through his processes of informal learning. In this regard, our conversations offered an example of some of the possible pathways and solutions that arise when looking beyond music learning cultures or early career transitions.

\section{Listening}

Simon's story about becoming a composer reflects a wide range of opportunities and experiences he had, sometimes facilitated by significant others, that developed or were related to his interest in music. His formal musical training began with free 
classical guitar lessons offered at his primary school. But Simon's unmediated experiences of music were equally rich and rewarding:

I have such vivid memories of going through vinyl collections either of my brother's or of my stepfather's at the time. And sort of figuring out very quickly how to turn an amplifier on and to use a turntable just so I could listen to music, because that, that was my thing. That and listening to, sort of, talking books you know. ... But yeah, I was really into music, at a really early age. But listening.

Simon's practice of listening, described here as an early, formative experience, was a recurring theme. As the interviews unfolded, I became aware of the different roles listening played in Simon's life. The act of listening to music was not just something he liked to do as a child, it formed a central part of his developing artistic practice and his current work as a composer. From a narrative therapy standpoint, listening emerged as a central theme in the plotline of his career story.

Simon recalled the feeling of "escapism" that came from "just sitting on the living room floor, putting record on, after record on, after record on." As our conversations continued, however, it became clear that for Simon these early experiences still resonated in his current practice:

If I sit here today and I think, "Okay, what is it that made, carved my artist's voice to where it is today," I would sort of-it would go back to listening to music again, and listening to other artists ... that's sort of how I've learnt. I'm a bit of a sponge like that. I sort of pull ideas from all over the place and then try to turn it into something. You know, that's how music has evolved. I'm not doing anything new, but it's certainly how I've progressed in the last eight years is ... absorbing. And when I hear stuff I listen to it on repeat endlessly, just going, "How do they do that? How do they do that?"

The theme of listening in the excerpts above show its development from a childhood pastime into a form of professional development, a process for selflearning, and as an escape, reflecting a core aspect of Simon's creative process.

\section{Uniqueness}

One of the things that struck me throughout my conversations with Simon was the value he placed on uniqueness, and how he associated the unique aspects of his work with what he described as an "experimental" work process:

I don't have an academic learning process at all. I have an experimental [process]. I'm in my laboratory doing things, and ... I don't think that you can ever say that

Canham, Nicole. 2021. Background music: Using narrative inquiry to explore the hidden aspects of musicians' career development. Action, Criticism, and Theory for Music Education 20 (4): 146-70. https://doi.org/10.22176/act21.1.146 
"I've got to the end of my experimental phase; now I'm settled as a composer" ... because then I've sort of stopped what I think makes me a unique composer, or what were one of the things that contribute to me sounding different from the next guy.

Simon's formal experience of music involved years of music exams and technical work through secondary school. Although these gave him a great appreciation of the value of a classical guitar playing technique and a love of performing, by his mid-teens Simon was feeling disengaged with formal music lessons. At this point, two significant events occurred. First, his instrumental music teacher, who was a jazz guitarist, recognised his waning enthusiasm and suggested that they abandon exams (and the repertoire and theory structure this imposed, although some formal structure-the lessons-remained in place). Instead, teacher and student improvised together, augmenting this with theory only as required. Second, around the same time, Simon's classroom music teacher invited him to use the music facilities during lunchtimes, and he began his first forays into the world of electronic and recorded music and composition.

These encouragements provided Simon with the environment and the tools needed to explore music through improvisation and experimentation. The impact of informal learning opportunities not only formed a second plotline in Simon's narrative, but also thickened out the meaning of these experiences to him; freedom to "see what happens" and the unique possibilities this afforded formed the basis of a strong sense of agency as a musician. I wondered, given that Simon's informal music learning experiences seemed so different from my very orthodox classical training, how these shaped his musician identity:

Nicole: Just then you made a distinction between learning music and then feeling like an artist. So, do you have a memory, a different memory of when you felt like, "Okay, this is it. I want to do this?"

Simon: Yeah. Secondary school when I was continuing my guitar lessons. I would have been around 14 or 15 then ... At that point, that's when I was going off learning music in the traditional way of learning music and doing your grades. I remember some really cool kids coming in to have guitar lessons, and I could play anything I wanted to by that point. So they thought I was really, really cool, and I thought, "Okay." That's quite an ego boost. There's something quite nice about that.

Canham, Nicole. 2021. Background music: Using narrative inquiry to explore the hidden aspects of musicians' career development. Action, Criticism, and Theory for Music Education 20 (4): 146-70. https://doi.org/10.22176/act21.1.146 
As Simon's narrative unfolded, he shared other memories of feeling good at music-making. A sense of success seemed to justify his persistence with music. Thus, a career development triumvirate emerges through Simon's story: an ongoing connection to what originally inspired his interest in music through listening (source of motivation and ownership), support for music-making that clearly suited his temperament and interests (supportive context in which to express agency), and early successes that cemented and later built upon his musical identity (opportunities for positive identity continuity and self-authorship).

Interpreting Simon's interviews from the point of view of a career counsellor, I started to see connections between the stories of his early musical interests and his current work. Simon's patterns of interest and engagement with music seem to endure across time, providing a sense of identity continuity:

Nicole: You also talked about this moment where you felt really cool because you could play the guitar.

Simon: Well, it's funny, having said that a moment ago, I now see how that type of competitiveness is still with me today. If I hear an artist that's invented a really cool, unique sound, I will ... If I hear somebody that's got a really cool, unique sound that I haven't come up with first, I'll be really envious, and I can't handle it. "How do they do that sound?"

Brave Decisions

One interview was set aside to discuss each participant's work through their choice of an artefact that they felt represented their practice. Simon chose an iPad application that he had been working with, because he felt it encapsulated the way in which he liked to work:

A lot of my most satisfying artistic jumps have been through chance and throwing the dice, a little bit, and seeing where they land. And ... sometimes they land and land a bit awkwardly, but you sort of see it through, and you go, "Well, I'm going to make it work. I'm going to try and make this work." And sometimes by putting in that effort, you actually come up with something that, to the listener, probably feels really planned and thought out ... I don't think we take enough risks in music very often, especially in my field. But the stuff that stands out, I think, is the stuff that has been quite brave, and it encourages you to make brave decisions.

Despite its significance for career outcomes, people may not be fully aware of their decision-making style or its implications. Simon's description of the need for risk-taking and for making "brave decisions" highlights not only his way of making

Canham, Nicole. 2021. Background music: Using narrative inquiry to explore the hidden aspects of musicians' career development. Action, Criticism, and Theory for Music Education 20 (4): 146-70. https://doi.org/10.22176/act21.1.146 
decisions, but also the self-belief required for such risk-taking. The career resources required to be brave, therefore, involve more than risk-taking: a certain level of self-confidence and resilience is also needed. Considering the excerpt above in relation to Simon's earlier descriptions of experimenting with music composition, he displays a high tolerance for the unexpected. Indeed, some of the outcomes of experiments-those things that are not $100 \%$ controlled-seem to have been very fruitful for his artistic development.

\section{The Power of Individual Career Stories}

A question at the beginning of this study was, what is Simon's career background music, the guiding beliefs and values that underpin his narrative? Two themes emerged from Simon's narrative: the ways in which personal resources significantly inform career expectations and aspirations and his own understanding of how an independent artistic outlook develops.

The themes of Simon's background music as he frames his career experiences and decisions include listening and independence. Listening to music is a central plotline of his story, and the meaning of listening-first as a behaviour (actor), then as a way of providing inspiration (agent), and finally, as a core creative process at the centre of his professional work (author, per McAdams and Olson 2010)-matures as his career narrative unfolds. From a narrative therapy standpoint, Simon's love of listening is an important recurring theme and a key aspect of his dominant story about being an intuitive and experimental artist. Listening is a tried and tested pathway for solutions-a way of relaxing or escaping, learning, and challenging himself, and sustaining motivation. Simon's recognition of listening as a career development resource is reflected in the way he has continued it as a form of practice from childhood through to his current work: "Whenever I hear something that challenges me, that's when I get excited.... For me, how I keep myself match fit as a composer is I just keep listening."

As Simon expands upon the theme of listening, he makes connections between earlier interests and experiences and aspects of his current practice in ways that sustain a strong sense of professional artistic identity. His ability to make these connections reveals particular types of personal resources that are invaluable for career development. Simon's love of listening reflects high levels of self-awareness. 
Not only is Simon narrating a coherent sense of professional identity, both to himself and to me through the listening plotline, but it also seems that he has a clear process, based upon listening, that he finds inspiring and motivating. Identity continuity and self-awareness are fundamental competencies for career development, and Simon's concept of his artistic process, evident through his narrative, provides strong evidence of these abilities.

Independence is also a key career development resource for Simon and part of his background music. His strong commitment to ideas of improvisation, experimentation, and a somewhat intuitive approach to many aspects of his work are connected to his early memories of improvisation in music lessons, which he described as revelatory, and other experiences where he felt unique. Receiving support and "permission" from significant others-his father and brother with the turntable, his high school music teacher encouraging his electronic compositionsalso reinforced his interest in listening to music and experimenting with making music. This encouragement seemed to be critical to the development of some key guiding beliefs that sustain Simon's artistic career activities.

MacNamara et al. (2008) stress that regardless of a musician's ability and developmental opportunities, an "individual will only realize their true potential when they are able to transfer from one stage of development to the next" (348). Making connections between early formative experiences and later career choices, as evident in Simon's narrative, provides a means of understanding how musicians utilise defining moments for navigating and narrating career transitions. This form of learning through experience supports the concept of biographicity proposed by Alheit (1994); Simon's approach to learning and professional life reflect the view that careers are "shapeable' and designable" (290). Simon's narrative highlights how rich career learning can be embedded in creative tasks, and he developed a personal framework of career learning directly from his music experiences and creative practice. Simon's understanding of his experiences, identity, learning processes, and career development choices appear interrelated, and his account and reflections confirm the suitability of narrative frameworks for understanding musicians' careers, and, perhaps, helping musicians understand their own careers through their narratives (Young and Collin 2004).

What career or learning decisions did Simon make based on his background music? Juuti and Littleton (2012) highlight the importance of "assuming agency in 
respect of one's own musicianship and career" (5), especially in managing career transitions. Simon expressed agency in several ways, and this in itself is important: Simon not only negotiates his identity through his career transitions, but he has also transformed his experiences into an awareness of his career development process. Simon's work choices, together with the themes of experimentation and listening that dominate his story, support the development of his expertise and provide him invaluable ways of understanding career change and transition. Listening to Simon's account as a career counsellor, his experiences are framed within an overall story of significant personal resources. His narrative shows how he has drawn upon his love of listening to music and his enjoyment of experimental and intuitive ways of working to address a range of career development challenges, including the transition into the profession and through it into his mid-career. Given that there is significant attrition as musicians move through early and mid-career transitions (Hennekam and Bennett 2016), Simon's solutions for maintaining a sense of identity continuity, motivation, and professional achievement provide a unique perspective on how he has successfully navigated career challenges.

As I read over my notes after our interviews and during the writing of this paper, I noticed how "seamless" the process of career development seemed to be from the point of view of Simon's identity continuity, and I wondered: Is it the same for everyone else? Is it something else as well-like being realistic, being flexible, being prepared or willing to do all of what you need to do, not just some bits of it? As much as I aimed to bracket myself as researcher, reflecting on the interviews and my comments, I see my desire for a formula for success or for guidance as reflecting a widely shared assumption that musicians need career advice in order to solve their work-related problems. Revisiting my conversation with Simon after completing my career counselling training forced me to consider that some of the most central drivers of career success for creative people might, in fact, be unteachableand that music careers education might be significantly reimagined for its empowerment value. Simon's narrative suggests that musicians need personal ways of sustaining certainty and confidence-effective guiding beliefs-much more than they need specific advice. Through the lens of narrative therapy, Simon demonstrates what is possible when effective guiding beliefs are internalised.

How, then, does overlaying a narrative therapy approach alter or enhance meaning for the narrator and understanding for the reader? Simon's interviews 
provide insight into his learning pathways, the patterns of meaning he ascribed to his early artistic experiences, his current activities, and his sense of agency and identity coherence. As a career counsellor using a narrative therapy lens, it is possible to listen in a completely different way to the experiences recounted. The patterns of meaning evident in the excerpts of Simon's story represent powerful solutions to shared challenges that at present appear to cause large numbers of the music workforce varying degrees of hardship and anguish. Simon's formative experiences were connected with creative independence through his interest in improvisation and experimentation and his love of listening. Simon referred repeatedly to these key components of his practice, and his sense of identity continuity is clear: Simon knows who he wants to be as an artist and how he will become that artist. This might be understood as the how and why of career behaviour in action (Savickas 2005).

Using a narrative therapy lens, these themes are also evidence of considerable personal resources that have sustained Simon's sense of artistic empowerment together with his motivation and agency (Spreitzer 1995). His creative identity and his ability and opportunities to control its development through listening, improvisation, and experimentation informed and sustained his independent career activities and professional self-concept. This finding is consistent with previous observations that early interests in artistic independence may constitute the kinds of "exploratory activit[ies]" that support the management of later career transitions (Blustein 1997, 267).

From a narrative standpoint, the excerpts from Simon's interviews are not only accounts of experience through story per Clandinin's (2006) approach to narrative inquiry, they are evidence of his beliefs, values, and capabilities for problem-solving in his creative life. Simon's appreciation of the intuitive aspects of his artistic practice and decision-making form the foundation of his problem-solving skills. His choice of creative tools reflects his work-related problem-solving capacities. Digital technology facilitated work practices in which he did not have to "rely on so many people" and enabled him to produce "certain textures and sounds." He credits technology (his artefact) with enabling him to make "brave" artistic choices which form part of his sense of artistic integrity, consistent with MacDonald et al.'s (2002) observations that the personal and professional are intertwined musicians' identities. Simon's continuous engagement with experimentation and creative 
risk-taking provide evidence of his own critical reflective practice (Thompson and Pascal 2012).

\section{Future Directions}

In studies conducted prior to the pandemic, people's narratives about work already reflected the impact of uncertainty on both their employment and well-being. Stories related to uncertainty are exacerbated by an individual's tendency to internalise work problems related to external opportunity structures as personal failings, rather than attribute them to structural conditions beyond their control (Brown, Hesketh, and Williams 2003; Moreau and Leathwood 2006). Opportunity structure problems persist, as does the tendency to internalise them as personal failings. After the COVID-19 pandemic began, some governmental responses to creative workers' plight due to the pandemic appeared to fuel this misguided reading of the challenge at hand, as well as underestimate the global implications for the arts and artists, including musicians (UNESCO 2020). Musicians need strong professional identities to navigate this crisis-driven context (see Simosi, Rousseau, and Daskalaki 2015) and a level of agency that extends beyond the scope of much of our current teaching and research.

The narrative presented here highlights connections between narrative inquiry and narrative therapy and illustrates the potential offered by using both lenses simultaneously to better understand the myriad ways musicians understand and narrate their identities and work experiences. Simon's story provides additional insight into existing occupational research and highlights new opportunities. First, there was a clear relationship between Simon's early experiences and later (high) levels of self-agency needed for independent career development. While the literature highlights the influence of early formative experiences in the development of musical identities (e.g., Davidson 2002; MacDonald, Hargreaves, and Miell 2002), there is still much to be learned about how early experiences shape a person's career expectations and decision-making style, and how they foster an individual's self-awareness of their own artistic and career intentions.

To that end there is something to be said for the convergence framework presented here in expanding the methodological possibilities for understanding musicians' career development. Simon's story offers a positive example of how career 
learning frameworks can be constructed independently and lead to a strong sense of professional identity. Given the evidence of student disengagement with careers education during study for a variety of reasons (Tolmie 2014; Tolmie and Nulty 2015), stories such as Simon's may assist educators to develop careers coursework and experiences that develop students' emerging professional identities in order to inspire voluntary (rather than obligatory) engagement with careers education. An approach developed with an appreciation of the benefits of narrative career counselling, rather than group industry information session style classes, may be a means of enhancing young musicians' self-awareness of their early career beliefs and improving the career outcomes for music graduates.

Bowman (2006) suggests that narratives reflect broader discourses than an individual's experience, and that therefore a narrative may not be an individually authentic account, but rather a dialogue between an individual and their experiences within a much larger cultural narrative. Musicians' accounts of their training often reflect confusion or conflict about the value of their skills beyond the school of music environment, the differences between training and the profession, and inevitable hardships that accompany making a life in music. These are not "helpful stories," in the narrative therapy sense. By acknowledging the limitations of the contemporary work context for musicians and by paying greater attention to individual solutions as they emerge in musicians' "little stories" (Bowman 2006, 9) of how they address their career challenges and opportunities, we might collectively identify potential solutions to shared challenges in ways that are mutually beneficial. Narrative inquiry combined with narrative therapy offers an important window into career development of musicians and the ways in which they construct identity continuity. By helping musicians become more aware of their narratives of themselves and their professional work, and by encouraging thick descriptions of their lives, it is possible to validate the unique solutions musicians bring to complex, shared challenges. Every person's "background music" matters when it comes to their career development. Finding ways to listen to it is important if we aspire to research that advances our understanding and makes possible alternative, more positive career outcomes for musicians. 


\section{About the Author}

Churchill Fellow, Dr Nicole Canham (clarinet and tarogato), is an award-winning and versatile musician who is committed to creating transformative arts and educational experiences and to building new audiences for art music. In 2020, Nicole joined the faculty of the Sir Zelman Cowen School of Music, Monash University, as Wind Program Coordinator. In this role, she focuses on performance, teaching and research, all of which are integral aspects of her artistic practice. Nicole completed a $\mathrm{PhD}$ on the career pathways of independent, classically trained musicians in 2016 and has presented her research at leading conferences around the world. Nicole is a qualified career development practitioner, completing a Graduate Diploma of Career Education and Development through RMIT in 2019. Her book, Preparing Musicians for Precarious Work, was published by Routledge in 2021.

\section{References}

Akkermans, Jos, Julia Richardson, and Maria L. Kraimer. 2020. The Covid-19 crisis as a career shock: Implications for careers and vocational behavior. Journal of Vocational Behavior 119: 103434. https://doi.org/10.1016/j.jvb.2020.103434

Alheit, Peter. 1994. The "biographical question" as a challenge to adult education. International Review of Education / Internationale Zeitschrift für Erziehungswissenschaft / Revue Internationale de l'Education 40: 283-98. https://doi.org/10.1007/BFo1257782

Atchley, Robert C. 1989. A continuity theory of normal aging. The Gerontologist 29 (2): 183-90. https://doi.org/10.1093/geront/29.2.183

Barrett, Margaret S., and Sandra L. Stauffer. 2009. Narrative inquiry in music education: Troubling certainty. Dordrecht: Springer Netherlands. https://doi.org/10.1007/978-94-007-0699-6

Bartleet, Brydie-Leigh, Dawn Bennett, Ruth Bridgstock, Paul Draper, Scott Harrison and Huib Schippers. 2012. Preparing for portfolio careers in Australian music: Setting a research agenda. Australian Journal of Music Education 1: 32-41.

Beckman, Gary D. 2007. "Adventuring" arts entrepreneurship curricula in higher education: An examination of present efforts, obstacles, and best practices. Journal of Arts Management Law, and Society 37 (2): 87-112.

Canham, Nicole. 2021. Background music: Using narrative inquiry to explore the hidden aspects of musicians' career development. Action, Criticism, and Theory for Music Education 20 (4): 146-70. https://doi.org/10.22176/act21.1.146 
Bennett, Dawn. 2008. Understanding the classical music profession: The past, the present and strategies for the future. Burlington, VT; Aldershot, Hants, England: Ashgate.

Blustein, David. 1997. A context-rich perspective of career exploration across the life roles. The Career Development Quarterly 45 (3): 260-74. https://doi.org/10.1002/j.2161-0045.1997.tbo0470.x

Blustein, David. 2006. The psychology of working: A new perspective for counseling, and public policy (The LEA series in counseling and psychotherapy). Mahwah, N.J.: Lawrence Erlbaum.

Blustein, David L., and Paige A. Guarino. 2020. Work and unemployment in the time of COVID-19: The existential experience of loss and fear. The Journal of Humanistic Psychology, 60 (5): 702-709. https://doi.org/10.1177/0022167820934229

Bowman, Wayne. D. 2006. Why narrative? Why now? Research Studies in Music Education, 27 (1): 5-20. https://doi.org/10.1177/1321103X060270010101

Bridgstock, Ruth. 2013. Not a dirty word: Arts entrepreneurship and higher education. Arts and Humanities in Higher Education 12 (2-3): 122-37. https://doi.org/10.1177/1474022212465725

Brown, Phillip, Anthony Hesketh, and Sara Wiliams. 2003. Employability in a knowledge-driven economy. Journal of education and work 16 (2): 107-126. https://doi.org/10.1080/1363908032000070648

Canham, Nicole. 2021. Preparing musicians for precarious work: Transformational approaches to music careers education. New York: Routledge.

Carr, Alan. 1998. Michael White's narrative therapy. Contemporary Family Therapy 20 (4): 485-503. https://doi.org/10.1007/s10551-013-1894-9

Carroll, David. 2010. Beyond graduation 2009: A report of the Beyond Graduation Survey. http://www.graduatecareers.com.au/wpcontent/uploads/2012/01/gcaoo1227.pdf

Carroll, David. 2015. Beyond graduation: A report of graduates' work and study outcomes three years after course completion. http://www.graduatecareers.com.au/wpcontent/uploads/2015/o7/Beyond_Graduation_2014.pdf

Canham, Nicole. 2021. Background music: Using narrative inquiry to explore the hidden aspects of musicians' career development. Action, Criticism, and Theory for Music Education 20 (4): 146-70. https://doi.org/10.22176/act21.1.146 
Clandinin, D. Jean. 2006. Narrative inquiry: A methodology for studying lived experience. Research Studies in Music Education 27 (1): 44-53. https://doi.org/10.1177\%2F1321103X060270010301

Cohen, Patricia. 2020. A "great cultural depression" looms for legions of unemployed performers. New York Times (December 14). https://www.nytimes.com/2020/12/26/arts/unemployed-performertheatre-arts.html

Creech, Andrea, Ioulia Papageorgi, Celia Duffy, Frances Morton, Elizabeth Haddon, John Potter, and Graham Welch. 2008. From music student to professional: The process of transition. British Journal of Music Education 25 (3): 315-31. http://doi.org/10.1017/s0265051708008127

Davidson, Jane W. 2002. The solo performer's identity. In Musical Identities, edited by Raymond A. R. MacDonald, David J. Hargreaves, and Dorothy Miell, 97-113. Oxford and New York: Oxford University Press.

Duffy, Ryan D., David L. Blustein, Matthew A. Diemer, and Kelsey L. Autin. 2016. The psychology of working theory. Journal of Counseling Psychology 63 (2): 127-48. http://dx.doi.org/10.1037/couoooo140

Furlong, Andy, and Andy Biggart, A. 1999. Framing "choices": A longitudinal study of occupational aspirations among 13-16-year-olds. Journal of Education and Work 12 (1): 21-35. https://doi.org/10.1080/1363908990120102

Gross, Sally-Anne, and George Musgrave. 2020. Can music make you sick? Measuring the price of musical ambition. London: University of Westminster Press. https://doi.org/10.16997/book43

Handy, Charles. 1989. The age of unreason. Boston, Massachussetts: Harvard Business School Press.

Hennekam, Sophie, and Dawn Bennett. 2016. Involuntary career transition and identity within the artist population. Personnel Review 45 (6): 1114-31. https://doi.org/10.1108/PR-01-2015-0020

Hennekam, Sophie. 2017. Dealing with multiple incompatible work-related identities: The case of artists. Personnel Review 46 (5): 970-87. https://doi.org/10.1108/PR-02-2016-0025

Canham, Nicole. 2021. Background music: Using narrative inquiry to explore the hidden aspects of musicians' career development. Action, Criticism, and Theory for Music Education 20 (4): 146-70. https://doi.org/10.22176/act21.1.146 
Juuti, Sini, and Karen Littleton. 2012. Tracing the transition from study to a contemporary creative working life: The trajectories of professional musicians. Vocations and Learning 5 (1): 5-21. https://doi.org/10.1007/s12186-011-9062-9

Krumboltz, John D. 2009. The happenstance learning theory. Journal of Career Assessment 17 (2): 135-54. http://doi.org/10.1177/1069072708328861

Law, Bill, Frans Meijers, and Gerard Wijers. 2002. New perspectives on career and identity in the contemporary world. British Journal of Guidance \& Counselling 30 (4): 431-49. https://doi.org/10.1080/0306988021000025637

MacDonald, Raymond A. R., David J. Hargreaves, and Dorothy Miell. 2002. Musical identities. Oxford; New York: Oxford University Press.

MacNamara, Áine, Patricia Holmes, and Dave Collins. 2008. Negotiating transitions in musical development: The role of psychological characteristics of developing excellence. Psychology of Music 36 (3): 335-52. https://doi.org/10.1177/0305735607086041

McAdams, Dan P., and Bradley D. Olson. 2010. Personality development: Continuity and change over the life course. Annual Review of Psychology 61 (1): 517-42. https://doi.org/10.1146/annurev.psych.093008.100507

Meijers, Frans, and Marinka Kuijpers. 2014. Career learning and career learning environment in Dutch higher education. Journal of Applied Research in Higher Education 6 (2): 295-313. https://doi.org/10.1108/JARHE-o6-20130025

Mitchell, Kathleen E., Al S. Levin, and John D. Krumboltz. 1999. Planned happenstance: Constructing unexpected career opportunities. Journal of Counseling and Development 77 (2): 115-24. https://doi.org/10.1002/j.1556-6676.1999.tbo2431.x

Moreau, Marie-Pierre, and Carole Leathwood. 2006. Graduates' employment and the discourse of employability: a critical analysis. Journal of education and work 19 (4): 305-324. https://doi.org/10.1080/13639080600867083

Morgan, Amanda. 2000. What is narrative therapy? Adelaide: Dulwich Centre Publications.

Canham, Nicole. 2021. Background music: Using narrative inquiry to explore the hidden aspects of musicians' career development. Action, Criticism, and Theory for Music Education 20 (4): 146-70. https://doi.org/10.22176/act21.1.146 
Morris, Linda. 2020. "Something out of a satire": Thousands in arts not saved by JobKeeper. The Sydney Morning Herald (April 20). https://www.smh.com.au/culture/art-and-design/something-out-of-asatire-thousands-in-arts-not-saved-by-jobkeeper-20200419-p54l94.html

Nichols, Jeananne, and Wesley Brewer. 2017. Why narrative now? Marking a decade of narrative inquiry in music education. Bulletin of the Council for Research in Music Education 210-211: 7-13. https://www.doi.org/10.5406/bulcouresmusedu.210-211.0007

Olckers, Chantal, and Eileen Koekemoor. 2017. Linking psychological ownership with subjective career success and positive work-related outcomes. In Theoretical orientations and practical applications of psychological ownership, edited by Chantal Olckers, Llewellyn van Zyl, and Leoni van der Vaart, 3-20. Springer International Publishing.

Parsons, Frank. 1909. Choosing a vocation. Houghton and Mifflin.

Potgieter, Ingrid. 2012. The relationship between the self-esteem and employability attributes of postgraduate business management students. SA Journal of Human Resource Management 10 (2). https://doi.org/10.4102/sajhrm.v10i2.419

Qian, Jinghua. 2020. I can't apply for another grant. Un Magazine 14 (2). http://unprojects.org.au/magazine/issues/issue-14-2/jinghua-qian/

Savage, Mark. 2020. Musicians will lose two-thirds of their income in 2020. BBC News (18 November). https://www.bbc.com/news/entertainment-arts54966060

Savickas, Mark. 2005. The theory and practice of career construction. In Career development and counseling: putting theory and research to work, edited by Steven D. Brown and Robert W. Lent, 42-70. Hoboken, NJ: John Wiley, 2005.

Savickas, Mark. 2011. Career counseling. Washington, DC: American Psychological Association.

Savickas, Mark. 2013a. Career construction theory and practice. Career development and counseling: Putting theory and research to work 2: 14783. Wiley.

Canham, Nicole. 2021. Background music: Using narrative inquiry to explore the hidden aspects of musicians' career development. Action, Criticism, and Theory for Music Education 20 (4): 146-70. https://doi.org/10.22176/act21.1.146 
Savickas, Mark. 2013b. The future needs a past: The career development profession yesterday and tomorrow. Paper presented at the National Career Development Association Global Conference, Boston, Massachusetts, July 10, 2013. https://www.youtube.com/watch?v=rJC6e2caZ6E

Simosi, Maria, Denise M. Rousseau, and Maria Daskalaki. 2015. When career paths cease to exist: A qualitative study of career behavior in a crisis economy. Journal of Vocational Behavior 91: 134-46. https://doi.org/10.1016/j.jvb.2015.09.009

Skaggs, Rachel, Alexandre Frenette, Sally Gaskill, and Angie L. Miller. 2017. Artists in their communities (SNAAP Annual Report). Strategic National Arts Alumni Project. Bloomington, IN: Indiana University.

Smilde, Rineke. 2009. Musicians as lifelong learners: Discovery through biography. Eburon Uitgeverij BV.

Spreitzer, Gretchen M. 1995. Psychological empowerment in the workplace: Dimensions, measurement, and validation. The Academy of Management Journal 38 (5): 1442-65. https://www.doi.org/10.2307/256865

Stauffer, Sandra L. 2014. Narrative inquiry and the uses of narrative in music education research. In The Oxford handbook of qualitative research in American music education, edited by Colleen Conway, 163-85. Oxford University Press. https://www.doi.org/10.1093/oxfordhb/9780199844272.013.010

Stets, Jan E., and Richard T. Serpe. 2013. Identity theory. In Handbook of social psychology, edited by Jon De Lamater, 31-60. Springer.

Thompson, Neil, and Jan Pascal. 2012. Developing critically reflective practice. Reflective Practice 13 (2): 311-25. https://doi.org/10.1080/14623943.2012.657795

Throsby, David, and Petetskaya, Katya. 2017. Making art work: An economic study of professional artists in Australia. Sydney, NSW: Australia Council for the Arts.

Tolmie, Diana. 2014. Identifying, analysing and aligning "the dream" with vocational preparation: An investigation into first-year music undergraduate career aspirations and motivations. In ISME Commission on the Education of the Professional Musician, edited by G. Carruthers, 73-85. Belo Horizonte, Brazil: International Society for Music Education.

Canham, Nicole. 2021. Background music: Using narrative inquiry to explore the hidden aspects of musicians' career development. Action, Criticism, and Theory for Music Education 20 (4): 146-70. https://doi.org/10.22176/act21.1.146 
Tolmie, Diana, and Duncan D. Nulty. 2015. Aligning student attitudes, assessment, and curriculum design: A case study using the "my life as a musician" vocational preparation strand. In Assessment in music education: From policy to practice, edited by Don Lebler, Gemma Carey, and Scott Harrison, 279-92. Champaign: Springer International Publishing.

UNESCO. 2020. Culture in crisis: Policy guide for a resilient creative sector. https://unesdoc.unesco.org/ark:/48223/pfoooo374631

University of Strathclyde and Bimrose, J. 2006. Labour market information for career decision-making. A report to Highlands and Islands Enterprise. Centre for Studies in Enterprise, Career Development and Work/Institute for Employment Research.

van den Eynde, Julie, Adrian Fisher, and Chris Sonn. 2015. Working in the Australian entertainment industry, Phase 2: Executive Summary. https://www.cacwa.org.au/documents/item/450

White, Cheryl. 2009. Where did it all begin? Reflecting on the collaborative work of Michael White and David Epston. Context 105: 59-60. https://dulwichcentre.com.au/where-did-it-all-begin-cheryl-white.pdf

Yeoman, Ruth. 2014. Conceptualising meaningful work as a fundamental human need. Journal of Business Ethics 125 (2): 235-51. https://doi.org/10.1007/s10551-013-1894-9

Young, Richard A., and Audrey Collin. 2004. Introduction: Constructivism and social constructionism in the career field. Journal of Vocational Behavior 64 (3): 373-88. https://doi.org/10.1016/j.jvb.2003.12.005

\section{Notes}

${ }^{1}$ For a detailed summary of the research methodology used in the full study, including interview and data analysis procedures, see Canham (2021).

2 The concept of a career portfolio-a suite of different activities, roles and income sources-was first proposed by Handy (1989) and it has since been taken up in the musicians' occupational literature as this is a common work pattern.

Canham, Nicole. 2021. Background music: Using narrative inquiry to explore the hidden aspects of musicians' career development. Action, Criticism, and Theory for Music Education 20 (4): 146-70. https://doi.org/10.22176/act21.1.146 